\title{
Behaviour of brown bears killing wild ungulates in the Cantabrian Mountains, Southwestern Europe
}

\author{
Juan Carlos Blanco • Fernando Ballesteros • \\ Alicia García-Serrano • Juan Herrero • Carlos Nores • \\ Guillermo Palomero
}

Received: 9 April 2010 /Revised: 19 October 2010 /Accepted: 25 October 2010 / Published online: 11 November 2010

(C) Springer-Verlag 2010

\begin{abstract}
Although brown bears (Ursus arctos) are known to be major predators of ungulates in North America and Northern Europe, there is little documentation regarding bear predation on wild ungulates in Southern Europe. We describe search, detection, killing and prey consumption behaviour by brown bears during seven attacks on $<1$-month roe deer, red deer and chamois fawns in spring in the
\end{abstract}

Communicated by C. Gortázar

Electronic supplementary material The online version of this article (doi:10.1007/s10344-010-0464-z) contains supplementary material, which is available to authorized users.

J. C. Blanco $(\bowtie) \cdot$ F. Ballesteros $\cdot$ G. Palomero

Brown Bear Foundation,

C/Isabel la Católica 13,

E-39007, Santander, Spain

e-mail: jc.blanco2503@gmail.com

F. Ballesteros

e-mail: fballes@terra.es

G. Palomero

e-mail: osopardo@grn.es

\section{A. García-Serrano}

Ega Wildlife Consultants,

C/Sierra de Vicort $31,1^{\circ}$ A,

E-50003, Zaragoza, Spain

e-mail: egasl@arrakis.es

J. Herrero

Area of Ecology, Technical School of Huesca,

University of Zaragoza,

E-22001, Huesca, Spain

e-mail: herreroj@unizar.es

C. Nores

INDUROT, University of Oviedo,

Campus de Mieres,

E-33600, Mieres, Spain

e-mail: cnores@uniovi.es
Cantabrian Mountains, north-western Spain. As soon as the bears detected a fawn by their smell or their mother's presence, they switched from routine foraging on plants and insects to an intensive search for the fawns, mainly using smell to comb a $0.5-1$ ha area for $15-45 \mathrm{~min}$. They killed the fawns either while the latter were resting or after a brief chase. The bears usually took their prey to dense vegetation, consuming it immediately. In four cases, 5-month-old cubs accompanying the female did not participate in the hunt. We also document the apparently non-predatory killing of a $40-\mathrm{kg}$ wild boar by a female bear with cubs surprised by a sudden encounter. They did not eat the boar after the attack.

Keywords Ursus arctos . Brown bear. Predation . Wild ungulates $\cdot$ Cantabrian Mountains $\cdot$ Spain

\section{Introduction}

Brown bears (Ursus arctos) can be important predators on ungulates in North America, where they mainly prey on moose (Alces alces), caribou (Rangifer tarandus) and elk (Cervus elaphus). Bears may also kill adult ungulates, but mainly concentrate on calves in the first 4 weeks after birth in spring and early summer (Barber-Meyer et al. 2008; Zager and Beecham 2006). In a review of black (Ursus americanus) and brown bear predation on ungulates in North America, Zager and Beecham (2006) suggested that predation is additive at low ungulate densities and can become compensatory as prey density approaches carrying capacity. In Sweden, bears killed $26 \%$ of moose calves, $92 \%$ of them $<5$ month old. Bear predation was probably additive to other natural mortality (Swenson et al. 2007).

Apart from Scandinavia and the Russian taiga (literature reviewed by Swenson et al. 2007), we know of no study 
related to brown bear predation on ungulates in temperate and southern Europe beyond food habits studies based on scat analysis and the finding of a chamois (Rupicapra pyrenaica) killed by a bear in the Apennines (Fico et al. 1984). In the three major studies on bear feeding habits conducted in the Cantabrian Mountains (Spain), few wild ungulates remains were found in scat. Roe deer only appeared in 1.7 and red deer (Cervus elaphus) in 1.5\% of 929 scats analysed by Clevenger et al. (1992a). The authors suppose that most ungulates were taken as carrion because roe deer hardly appeared in scats found in spring, when the females give birth. Roe deer (Capreolus capreolus) was the only species to appear in over ten scats of the 261 analysed by Braña et al. (1993). Finally, out of the 1,500 bear scats analysed by Naves et al. (2006), roe deer appeared in 45 , chamois in five, red deer in two and wild boar (Sus scrofa) in one. The authors did not ascertain whether the ungulates in the scat were prey or carrion.

In this note, we describe the searching behaviour, detection, killing and consumption of wild ungulate fawns by brown bears in the Cantabrian Mountains, a context with roe and red deer, chamois and wild boar as potential prey. To our knowledge, this is the first time such behaviour has been described in the scientific literature in Europe. Preliminary descriptions by our research team have been published in popular and technical books (e.g. Palomero et al. 2007a).

\section{Study area and methods}

In the Cantabrian Mountains (North-western Spain), there are two critically endangered bear subpopulations partially separated by a strip of $50-80 \mathrm{~km}$ of low-quality habitat. The western subpopulation $\left(2,800 \mathrm{~km}^{2}\right)$ had 18 and 17 females with cubs of the year in 2007 and 2008, respectively. In the eastern subpopulation $\left(2,100 \mathrm{~km}^{2}\right)$ there were three and two females with cubs of the year in 2007 and 2008 (Palomero et al. 2009). The bears appear to prefer habitat that is a complex of deciduous forests, shrubs and grasslands at 1,100-1,400 m, i.e. above areas of intense agricultural activity, but below the subalpine zone (see Clevenger et al. 1992b and Palomero et al. 2007b for a detailed habitat description).

We monitored the Cantabrian Mountains bear population from 1988 to June 2010 using the number of females with cubs as an index in order to ascertain population trends (Palomero et al. 2007b) and study their behaviour. The main method for detecting bears (mainly family groups) was to scan with telescopes from vantage points, starting at dawn. Observations were conducted from a distance of $300-1,500 \mathrm{~m}$ for the whole time that they were in sight, sometimes during the entire daylight period. No bears were radio collared. All the data we present here were collected by the authors or Fundación Oso Pardo (Brown Bear Foundation) rangers under the authors' supervision. To avoid inaccuracies, accounts from other observers have been excluded.

\section{Results}

Between 1988 and June 2010, we observed 141 different bear family groups (females with cubs) over 958 days. The average time per observation day was $119 \mathrm{~min}$ (range, $<1 \mathrm{~min}-10 \mathrm{~h} 20 \mathrm{~min}$; data from 2009,113 observation days). We also observed solitary bears (probably a few hundred) over periods lasting from a few seconds to the entire daylight period. Over the last 23 years, on seven occasions we observed bears predating on fawns in spring (five roe deer, one red deer and one chamois). Furthermore, a female bear with two cubs was seen to kill a wild boar weighing approximately $40 \mathrm{~kg}$. As it did not appear to kill the boar to eat, we did not include the incident as a case of predation.

\section{Bears predating fawns}

We observed the first four cases of predation between 10 and 14 June 2000 in Degaña Hunting Reserve (Asturias). Over 5-days monitoring, we saw a female with three cubs of the year hunt and eat small roe deer fawns on 4 days. On 15 June, the female disappeared after a male bear killed the three cubs (Palomero et al. 2007a). In addition, we observed three other solitary bears predating roe deer (15 May 2005, Somiedo Nature Park, Asturias), red deer (4 May 2007, Fuentes Carrionas Nature Park, Palencia) and chamois fawns (27 May 2010, Somiedo N. P.).

Attacks and predation on fawns always occurred in spring. In the Cantabrian Mountains, roe deer usually give birth between mid-May and mid-June, whereas red deer and chamois do so in May (Blanco 1998). Attacks always occurred a few days or weeks after the fawns' birth (Table 1).

The hunting sequence was very similar in all seven cases. While routinely foraging amongst bracken, ferns and woodland patches, grazing, digging roots and turning over rocks, the adult bears detected the presence of deer and began actively searching for fawns. Prior to predating on the chamois fawn, the bear was foraging in subalpine habitat (treeless, steep mountain slopes of grassland and rocks).

On four occasions, their search seemed to be triggered by the flight of an adult female deer or a herd of chamois. On three occasions, the bears sniffed the air before starting to search, the smell of the fawns or female bears or/and 
Table 1 Summary of eight cases of bears killing ungulates

\begin{tabular}{|c|c|c|c|c|c|c|c|}
\hline Bear & $\begin{array}{l}\text { Ungulate } \\
\text { killed }\end{array}$ & Date & Time+ & $\begin{array}{l}\text { Fawn } \\
\text { detection }\end{array}$ & $\begin{array}{l}\text { Search } \\
\text { time }\end{array}$ & Capture & Prey consumption \\
\hline $\begin{array}{l}\text { Female with } 3 \\
\text { cubs }^{\mathrm{a}}\end{array}$ & Roe deer fawn & 10.6 .2000 & 9.37 & $\begin{array}{l}\text { Scent. Mother } \\
\text { present }\end{array}$ & - & Leapt on resting fawn & $\begin{array}{l}40 \text { min in thick } \\
\text { vegetation }\end{array}$ \\
\hline $\begin{array}{l}\text { Female with } 3 \\
\text { cubs }^{\mathrm{a}}\end{array}$ & Roe deer fawn & 11.6 .2000 & 13.33 & Mother ran & $20 \mathrm{~min}$ & $\begin{array}{l}\text { Fleeing fawn caught in } \\
\text { paws after } 20 \text {-m chase }\end{array}$ & No data \\
\hline $\begin{array}{l}\text { Female with } 3 \\
\text { cubs }^{\mathrm{a}}\end{array}$ & Roe deer fawn & 12.6 .2000 & 14.30 & Mother ran & $40 \mathrm{~min}$ & Unknown & $\begin{array}{l}20 \text { min in thick } \\
\text { vegetation }\end{array}$ \\
\hline $\begin{array}{l}\text { Female with } 3 \\
\text { cubs }^{\mathrm{a}}\end{array}$ & Roe deer fawn & 14.6.2000 & 19.28 & Scent & $53 \mathrm{~min}$ & Pounced on resting fawn & $\begin{array}{l}53 \text { min in thick } \\
\text { vegetation }\end{array}$ \\
\hline Solitary bear & Roe deer fawn & 31.5 .2005 & 8.00 & Unknown & - & Pounced on resting fawn & In thick vegetation \\
\hline Solitary bear & Red deer fawn & 4.5 .2007 & 9.00 & Scent & $15 \mathrm{~min}$ & $\begin{array}{l}\text { Caught resting fawn in } \\
\text { mouth }\end{array}$ & $\begin{array}{l}30 \text { min in thick } \\
\text { vegetation }\end{array}$ \\
\hline Solitary bear & Chamois fawn & 27.5.2010 & 7.50 & $\begin{array}{l}\text { Herd ran. } \\
\text { Scent }\end{array}$ & $45 \mathrm{~min}$ & $\begin{array}{l}\text { Caught resting fawn in } \\
\text { mouth }\end{array}$ & $\begin{array}{l}30 \text { min on open } \\
\text { mountain slope }\end{array}$ \\
\hline $\begin{array}{l}\text { Female with } 2 \\
\text { cubs }^{\text {b }}\end{array}$ & $\begin{array}{l}\text { Wild boar } \\
\text { (13 months old })\end{array}$ & 22.4 .2006 & 7.20 & Cubs ran & $0 \mathrm{~min}$ & $\begin{array}{l}\text { Boar grasped in paws } \\
\text { and bitten on back of } \\
\text { the neck }\end{array}$ & Boar not eaten \\
\hline
\end{tabular}

+ Time hunt started

${ }^{a}$ Same family group; cubs 5 months old

${ }^{\mathrm{b}}$ Cubs 15 months old

sighting the females likely triggering their behaviour shift from routine foraging on plants and invertebrates (Table 1).

During the search, the bears combed a $0.5-1$ ha area, actively zigzagging and often doubling back, sniffing the ground like a bloodhound or raising their head to sniff the air. They also sometimes stood up partially or fully on their hind legs to scan above the line of vegetation. On the five occasions that hunting was timed, the search lasted 45, 45, 40, 15 and $20 \mathrm{~min}$ (the last case included a 20-minute pause).

The hunting bears detected the fawn as follows: when the fawn was running about $30 \mathrm{~m}$ away (one/seven); when the roe deer female that was resting with the fawn ran out (two/seven); and, apparently, when a fawn was located lying down (four/seven). On one occasion, after being flushed out, the roe deer female attempted a distraction feint, but failed to distract the bear's attention (Table 1).

On one occasion, a female bear pursued a fawn that emerged a few metres away from her, knocking it down approximately $20 \mathrm{~m}$ away and then putting it in her mouth. Just prior to capture, the roe deer fawn tried to dodge, but was easily caught. On six other occasions, the bears caught the resting fawn without a chase. On three other occasions, the bear stopped briefly in front of the resting fawn (perhaps to pinpoint it) and then pounced before putting it in its mouth. One parabolic leap resembled that of a red fox (Vulpes vulpes) pouncing on voles (Microtus sp.). In the three remaining cases, the bears took the fawns from the ground in their mouth without any apparent pausing or pouncing. In all but one case, the fawns appeared to die instantly. In one case, the bear was seen shaking the fawn in its mouth.

After catching the fawns, the bears quickly carried them in their mouth several dozen metres away to an area of thick vegetation cover and ate them immediately. Only the bear that captured the chamois fawn in subalpine habitat consumed it in the open. Average prey comsumption time was 35 min (range: $20-53 \mathrm{~min} ; n=5$ ). Rapid removal of the dead fawn may be to prevent possible harassment by wolves (Canis lupus), corvids or raptors (Table 1).

In the four cases that hunting involved a female bear with cubs about 5 months old, the latter tried to follow the female at a short distance, but were sometimes left behind. The cubs never took part in the fawn kill. In three cases, the cubs also ate the dead fawn after it had been moved to cover. In two of those cases they did so in an orderly way, but the other case involved squabbling. During the fourth attack, the cubs were separated from the female during the search and she ate the prey alone.

In five of the seven cases the bears rested after consuming the prey. In the remaining two cases, two solitary bears began a new search for fawns, which ended unsuccessfully 15 and 25 min later.

During the hunts, the bears showed no inclination to attack adult deer, chamois or a second fawn. In both cases that the fawn's mother was near the hunting bear, the latter appeared uninterested in attacking her. In one case, when twin roe deer fawns ran clumsily through the scrub, the female bear killed one and ignored the second. 
Attack on a wild boar following a sudden encounter

Our observation of a female bear killing a 13-month-old wild boar (estimated weight $40 \mathrm{~kg}$ ) should perhaps not be regarded as a case of predation. On 22 April 2006 at 07.20 in Somiedo Natural Park (Asturias), a female was resting on a rocky slope among ash and walnut trees with her two second-year cubs (estimated weight: $35-40 \mathrm{~kg}$ ). The juveniles suddenly started running fast towards the trees, and the female followed. The juveniles separated and one encountered a young wild boar. The female positioned herself above the boar on the slope, cutting off its escape and then attacked it with a bite to the back of the head, shaking it and leaving it lifeless on the ground. She immediately left. One juvenile approached the corpse, sniffed it briefly and followed the mother. Monitoring throughout the rest of the day revealed that they did not approach the dead boar again.

The fact that the bears did not eat the boar suggests it was a defensive attack rather than predation. The female probably launched a swift attack to protect the frightened juveniles. This case recalls those described in North America by Herrero (1985), when female grizzlies with cubs attacked when surprised during sudden encounters with people.

\section{Discussion}

Cases of bears hunting neonate deer and chamois in spring or early summer in the Cantabrian Mountains fit with the brown bear predatory behaviour on ungulates described in North America (Zager and Beecham 2006) and Scandinavia (Swenson et al. 2007). Although there are a large number of observations in North America of bears predating adult ungulates (Zager and Beecham 2006), we have never observed a single case. The attack on a $40-\mathrm{kg}$ wild boar was probably a preventive attack to protect the cubs from a perceived threat.

Bears predating on neonate ungulates in the Cantabrian Mountains showed opportunistic behaviour. The search for ungulate neonate was triggered when the bears perceived a good opportunity during their regular foraging on plants and invertebrates. Predation on ungulates is apparently a learned behaviour (Zager and Beecham 2006). Observations of brown bears in Yellowstone National Park (French and French 1990) indicate that the feeding habits of individual bears within a population occur along a gradient from highly predatory to little or no predatory activity. The female bear with cubs that we saw hunting roe deer fawns on four days in May 2000 is (apart from the female with cubs that killed the wild boar) the only one observed during 958 days' monitoring (approximately1,900 observation hours) females with cubs from 1988 to June 2010. She was in mixed habitat of broom stands, fern stands and grassland, which is ideal birthing habitat for roe deer females, in the area of the Cantabrian Mountains with the highest density of roe deer (Teresa Corominas, pers. com.). That female could be a specialist hunter of roe deer neonates.

The traditional basic predatory ethogram comprises three phases: search, pursue and capture (MacArthur and Pianka 1966). The hunting bears we observed spent most of their energy on the search of fawns hidden in vegetation. The pursue phase was present in only one of seven huntswhen a roe deer fawn left its refuge and ran 20 metres before the bear caught it - and lasted a few seconds. Capture involved no great effort in all cases. The extreme vulnerability of neonate ungulates makes the bear predatory behaviour much simpler than that of the ethogram proposed by MacNulty et al. (2007) for wolves and other large carnivores.

Our data do not allow assessment of the impact of bear predation on ungulate populations. In the Cantabrian Mountains, there are approximate densities of five and one bear $/ 100 \mathrm{~km}^{2}$ in the western and eastern subpopulations, respectively. Densities of ungulates are very variable, but 1.6-6.6 roe deer, 2.2-6.3 red deer, 5-14 chamois and $1.2-3.0$ wild boar $/ \mathrm{km}^{2}$ have been estimated in different parts of the Cantabrian bear range (Blanco 1998; Nores et al. 2000; Pérez-Barbería et al. 2009). Excluding the data on solitary bears, for which monitoring effort has not been quantified, we have only seen one female hunting ungulates out of 141 different family groups observed in 23 years, and 0.4 hunts/100 monitoring days devoted to females with cubs, many in spring. These figures suggest that the impact of bear predation on the ungulate population is probably very small. However, in order to be sure, ungulate mortality would have to be studied, requiring fawns to be tagged (Barber-Meyer et al. 2008; Swenson et al. 2007).

Acknowledgements We thank the rangers of the Fundación Oso Pardo (Brown Bear Foundation) for their enthusiastic efforts. The environmental agencies of Galicia, Asturias, Castilla y León and Cantabria, the Spanish Ministry of the Environment, the European Union Life Projects and the Fundación Biodiversidad provided funds for the long-term bear monitoring. T. Corominas (Biodiversity and Landscape Directorate of Asturias) provided unpublished figures on roe deer densities, Dr. Y. Cortés and two anonymous referees reviewed the manuscript and L. Ashcroft improved the English.

\section{References}

Barber-Meyer SM, Mech LD, White PJ (2008) Elk calf survival and mortality following wolf restoration to Yellowstone National Park. Wildl Monogr 169:1-30 
Blanco JC (1998) Mamíferos de España, Vol II Cetáceos, Artiodáctilos, Roedores y Lagomorfos. Ed GeoPlaneta, Barcelona

Braña F, Naves J, Palomero G (1993) Hábitos alimenticios y configuración de la dieta del oso pardo en la Cordillera Cantábrica. In: Naves J, Palomero G (eds) El oso pardo (Ursus arctos) en España. ICONA, Madrid, pp 81-104

Clevenger AP, Purroy FJ, Pelton MR (1992a) Food habits of brown bears (Ursus arctos) in the Cantabrian Mountains, Spain. J Mammal 73:415-421

Clevenger AP, Purroy FJ, Pelton MR (1992b) Brown bear habitat use in the Cantabrian Mountains, Spain. Mammalia 53:206-213

Fico R, Locati M, Lovari S (1984) A case of brown bear predation on Abruzzo chamois. Säugetierkdl Mitt 31:185-187

French SP, French MG (1990) Predatory behavior of grizzly bears feeding on elk calves in Yellowstone National Park, 1986-88. Int Conf Bear Res and Manage 8:335-341

Herrero S (1985) Bear attacks. Their causes and avoidance. Lyons and Burford, New York

MacArthur RH, Pianka ER (1966) On optimal use of a patchy environment. Am Nat 100:603-609

MacNulty DR, Mech LD, Smith DW (2007) A proposed ethogram of large-carnivore predatory behavior, exemplified by the wolf. J Mammal 88:595-605

Naves J, Fernández-Gil A, Rodríguez C, Delibes M (2006) Brown bear food habits at the border of its range: a long-term study. $\mathrm{J}$ Mammal 87:899-908
Nores C, Fernández-Gil A, Corral N (2000) Estimación de la población de jabalí (Sus scrofa) por recuento de grupos familiares. Nat Cantabr 1:53-59

Palomero G, Ballesteros F, Blanco JC, García-Serrano A, Herrero J, Nores C (2007a) Osas. El comportamiento de las osas con crías en la Cordillera Cantábrica, Fundación Oso Pardo and Fundación Biodiversidad, Madrid

Palomero G, Ballesteros F, Blanco JC, Nores C, Herrero J, GarcíaSerrano A (2007b) Trends in number and distribution of brown bear females with cubs-of-the-year in the Cantabrian Mountains, Spain. Ursus 18:145-157

Palomero G, Blanco JC, Ballesteros F, García-Serrano A, Herrero J, Nores C (2009) Veinte años tras las osas con crías de la cordillera Cantábrica. Quercus 281:14-21

Pérez-Barbería FJ, Palacios B, González-Quirós P, Cano M, Nores C, Díaz A (2009) La evolución de la población del rebeco en la Cordillera Cantábrica. In: Pérez-Barbería FJ, Palacios B (eds) El rebeco cantábrico Rupicapra pyrenaica parva. Conservación y gestión de sus poblaciones. Ministerio de Medio Ambiente y Medio Rural y Marino, Madrid, pp 106-125

Swenson JE, Dahle B, Busk H, Opseth O, Johansen T, Soderberg A, Wallin K, Cederlund G (2007) Predation on moose calves by European brown bears. J Wildl Manage 71:1993-1997

Zager P, Beecham J (2006) The role of American black bears and brown bears as predators on ungulates in North America. Ursus 17:95-108 